\title{
Hospitalized Elderly: Understanding about Their Rights
}

\begin{abstract}
Débora Rodrigues Alves de Lima1, Patrícia Serpa de Souza Batista², Indiara Carvalho dos Santos Platel ${ }^{3}$, Wiliana Aparecida Alves de Brito Fernandes ${ }^{4}$, Priscilla de Freitas Farias ${ }^{5}$, Jessyka Cibelly Minervina da Costa Silva ${ }^{6}$, Zirleide Carlos Felix ${ }^{7}$, Mirelle Bomfim Simões ${ }^{8}$, Thayana Jovino Borja ${ }^{5}$, Irany Carvalho da Silva ${ }^{5}$
\end{abstract}

\section{Abstract}

Objective: This study aimed to investigate the understanding of the elderly about their rights as hospitalized individuals and to find out

Methods: This is an exploratory qualitative research conducted among 20 hospitalized elderly, developed at the Medical Clinic Unit of the University Hospital Lauro Wanderley, the Federal University of Paraíba, located in the city of João Pessoa-PB. The empirical material was collected using semi-structured interview technique and analyzed using the Content Analysis Technique. The study was approved by the Research Ethics Committee of CAAE N 38746614.9.0000.5183.

Results: The interpretative analysis of the interviews enabled the construction of two categories: Senior hospitalized citizens understanding about their rights and Rights respected by professionals to assist the elderly.

Conclusion: We conclude that the elderly showed know about their rights they enjoy and that professionals seek to provide a humane and dignified care, respecting the rights of hospitalized elderly. It is expected that the data can support further researches about the subject.

Keywords

Elderly; Hospitalization; Patient Rights. about their rights by health professionals.

1 Nurse, Member and Researcher in Studies and Research Nucleus in Bioethics and Palliative Care at Federal University of Paraíba, NEPBCP/UFPB, *

2 Nurse, Doctor in Education, Professor of the Postgraduate and Graduate Nursing Program at Federal University of Paraiba. Member and Researcher in Studies and Research Nucleus in Bioethics and Palliative Care, NEPBCP/ UFPB,

3 Nurse, Master in Nursing at Federal University of Paraiba, UFPB,

4 Nurse, Master's Student of the Postgraduate Nursing Program at Federal University of Paraiba, Member of the Research Group in Adult Health and the Elderly, GEPSAI/UFPB,

5 Nurse at Federal University of Paraiba, UFPB, *

6 Student in Nursing at Federal University of Paraiba, Member and Researcher in Studies and Research Nucleus in Bioethics and Palliative Care at Federal University of Paraíba, NEPBCP/UFPB,

7 Nurse, Master in Nursing at Federal University of Paraiba/UFPB, Professor of Graduate Nursing Program at Higher Education Institute of Paraiba, Member and Researcher in Studies and Research Nucleus in Bioethics and Palliative Care, NEPBCP/UFPB, *

8 Nurse at João Pessoa University Center/ UNIPE, *

*: João Pessoa, Paraíba, Brazil.

Contact information:

Débora Rodrigues Alves de Lima.

\section{Introduction}

Brazil is passing through a time of demographic transition, with significant changes in the age pyramid. Life expectancy at birth increased ”deboraufpbsud@gmail.com 
from 50 to 73 years old, what resulted in increase of the number of older people in the population. Estimates indicate that over the next 40 years, the elderly population will increase from less than 20 million seniors to 64 million in 2050 [1].

It is worth recognizing that the increasing number of elderly people is influenced by several factors, including the decrease of the fertility rate, which reflects in a higher growth of this age group [2]. In this context, the population profile is showing changes that generate concerns setting of care, because the absentminded population is more susceptible to illness than young adults, so they need attention and special care [3].

Care for the elderly should be based on the maintenance of health, an expectation of active life that aims to functional independence and autonomy. From this perspective, it emphasizes the growing number of elderly who need special care and provided by health professionals [4]. This new scenario requires the construction and implementation of public policies that assist this population and, above all, a health system which is prepared to accommodate the specificities of this demand [5].

In this context, there is the National Policy for the Elderly (PNI), which aims to ensure social rights for the elderly, in order to create conditions to promote autonomy, integration and effective participation of the elderly in society, reaffirming the right to health at various levels SUS care, through Law N 8.842/94 and Decree No 1.948/96 [6].

The Law N 8.842/94, regulated by Decree $N^{\circ}$ 1.948/96, which provides for the National Policy for the Elderly, establishes the National Council for the Elderly and other measures, emphasizes in its A 4, item VIII, and A 17, the elderly are entitled to preferential treatment in state and private institutions of health, such as clinics, hospitals, laboratories and health care [6-7].

The National Health Policy of Seniors aims to promote, maintain and restore the autonomy and independence of elderly individuals, with individual and collective measures which should be directed to this end, in line with the principles and guidelines of the Unified Health System. The aim of this policy is applicable to all Brazilian citizens, men and women, aged 60 or older [8].

In hospitals, the National Health Policy for the Elderly, by Decree $N^{\circ}$ 2.528/2006, deals with the assistance to the elderly needs and establishes specific criteria to meet this population, since elderly patients are within the concept of vulnerability and health services must be prepared to identify these patients and provide them with a differentiated assistance [8].

Regarding hospitalization, the hospitalized elderly, more often, for longer periods, are being affected by diseases and chronic diseases. In addition, hospitalization is lived more complex because, in most situations, it is easily associated with death and dependence and experienced with great stress, anguish and anxiety [9-10].

To care for hospitalized patients, professionals should have the ability to establish a relationship of complicity, treating those with dignity and respect for their rights, recognizing and valuing their history, beliefs, values and needs. Therefore, it is evident the need for professionals to be prepared and qualified to meet this age group, for the care of the elderly will require knowledge and actions guided by ethical values [11].

Before the above considerations, it highlights the importance of investigating whether the hospitalized elderly are either not aware of the rights, and whether they are being respected by health professionals with respect to their rights. The option to study this issue comes, initially, from the personal affinity in working with the elderly population, which began during the graduation, when I had the opportunity to attend theoretical and practical disciplines whose contents dealt with the care of the elderly, especially in the hospital context. Given the large number of hospitalized elderly and the importance of guaranteeing their rights, I justify my interest in conducting this study, which has the following guiding issues: What is the understanding 
of the elderly about their rights as hospitalized individuals? Elderly hospital patient rights are being respected by health professionals?

Considering the proposed questions, this study aims to: investigate the understanding of the elderly about their rights as individuals hospitalized and determine, from the perspective of hospitalized elderly, the respect for their rights by health professionals.

\section{Methods}

It is a study of exploratory type and qualitative nature. The exploratory research has as main purpose to develop, clarify and modify concepts and ideas, in order to get a general understanding of a certain fact [12]; since qualitative research investigates aspects that appreciate the values, beliefs and experiences that permeate human relationships allowing the choice of this approach, because the study investigated the understanding of the elderly about their rights as hospitalized individuals [13].

The survey was conducted in the Unit of Clinical Medicine, University Hospital Lauro Wanderley (HULW), and Federal University of Paraíba, located in the city of João Pessoa-PB. The choice for this location was because it is a service that presents a significant demand for hospitalized elderly patients. Currently, the sector has 24 active beds, although not exclusive in senior care.

The study population consisted of 20 elderly hospitalized in the mentioned Clinical Unit. They were selected using the following inclusion criteria: being 60 or older, hospitalized in that unit for more than 48 hours, voluntarily agree to participate in the study, present preserved cognitive conditions and general condition to allow their participation in research activities proposals.

The data were collected from January to March 2015, through the Interview Technique. For this, we used an interview guide with questions about sociodemographic data and issues relevant to the objectives proposed in the study. The empirical material was seized by the recording system, respecting the decision of the participants on the use of this instrument.

Empirical data from the interviews were transcribed verbatim and analyzed qualitatively through Content Analysis Technique proposed by Bardin (2011), which consists of three stages: the first concerns the pre-analysis, the second focuses on material exploration and the third refers to the processing and interpretation of the results [14].

The pre-analysis is the phase of the organization itself, in order to operationalize and systematize initial ideas; the exploration phase of the material is the definition of categories and coding. The raw data are organized and grouped into categories, through which one can describe the characteristics of the empirical material; and the last phase is the processing and interpretation of results. At that time it is attributed meaning to text features, which are summarized after treatment and presented in the form of categories [14]. In order to ensure the anonymity of study participants, they were coded following the interview of the order, as I. 1 to I. 20. The I. 1 corresponds to the first interviewee elderly, and so on.

Regarding the ethical position of the research, the study was guided by the Guidelines and the Regulatory Standards laid out in the National Health Council Resolution $N^{\circ}$ 466/2012. Information regarding the research was included in the Informed Consent [15]. Note that the survey was started after the project was approved by the Research Ethics Committee of the University Hospital Lauro Wanderley (HULW), Federal University of Paraíba - UFPB, with CAAE N ${ }^{\circ}$ 38746614.9.0000.5183. 


\section{Results}

\section{Characterization of the participants}

The study population consisted of 20 elderly patients hospitalized in the Clinical Unit of HULW $40 \%$ (8) were female and 60\% (12) were male. Regarding the marital status of elderly respondents, $65 \%$ (13) are married, 15\% (3), single, 10\% (2), divorced, and $10 \%$ (2), widowers. Regarding the age, it ranged from 60 to 79 years old, and what prevailed was 60-69 years old, with 75\% (15 participants).

Concerning schooling, 20\% (4) of the participants are illiterate; $25 \%$ (5) attended the elementary school; 30\% (6), elementary school II; 10\% (2), high school, and 15\% (3) higher education. The main professions/occupations of the participants who stood out were: farmer, with 30\% (6) and master builder, with 10\% (2). Regarding housing, 70\% (14) reside on the property itself, $20 \%$ (4) in rental property, and $10 \%(2)$, given property.

With respect to the people with whom the elderly live, 70\% (14) are spouse, 20\% (4) live with children, $5 \%$ (1) alone, and 5\% (1) with other people.

\section{Analysis of the empirical material}

The empirical material of the study was derived from the following guiding questions: What is the understanding of the elderly about their rights as hospitalized individuals? Elderly hospital patient rights have been respected by health professionals?

For a better understanding of the data analysis, the answers obtained from these questions will be presented in two categories: 'Hospitalized elderly understanding about their rights' and 'Rights respected by professionals to assist the elderly'.

\section{Category I. Understanding of the hospitalized elderly about their rights}

In this category, the discourse elderly about their rights as hospitalized patients. Analyzing the con- tent expressed in their statements, there were listed two subcategories:

\section{Subcategory 1 . The right to have an escort}

When asked about the rights they have as hospitalized patients, the respondents mentioned several, among them the most cited was the right to have a companion, found in these testimonials:

I believe that I have the right to have a companion, because not everyone can do something alone, need help.

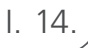

I know that the companion is a right of mine and it is an obligation of the hospital to accept my companion.

First be respected, this is the main law of the elderly. Another law that I can think of is to have a companion.

\section{Subcategory 2 . The right to health, information and autonomy}

Although the right to have a companion has been the most mentioned in the interviews, many seniors also mentioned others such as the right to health, to information and autonomy.

Initially, there are emphasized two speeches, whose approach reflects on the right to health, linking it needs assistance for differentiated health, recognizing the elderly in their weaknesses as shown below:

We all have rights, we all have a right to health, to be admitted, to be forwarded, to be informed, but the elderly, for his greater need and disability as a human being, and I think that the treatment with them should be respected in this sense, human rights. 
Law of the elderly is [...] health, education, which are rights that are in our constitution, but that as elderly often even to seek these rights, we must seek justice.

The respondent (I. 09) addressed the right to information. For hospitalized patients, this information is consolidated through verbal communication, and when that communication involves elderly patients, it is necessary to highlight the importance of attention and the use of clear language in order to establish a relationship of respect between him and the professional. Corroborating this assertion, we highlight the following statements:

All professionals ask if I'm okay, tell what they will do, if they will check the blood glucose level, see the pressure [...].

My rights were considered, look, they always explain when it comes to accomplish something, is a medication, an examination, any other thing.

Explain what they are doing, look this serum is to do this, it is important for this reason, everything they say.

Regarding the testimonies presented, respondents had the right to receive information, respected by health professionals. You can see the satisfaction of patients and to information on nursing procedures and that there is a positive interaction between patients and nursing professionals, through communication, as evidenced in these words: "They always explain when it comes to doing something" "explain what they are doing", which shows the quality of the services provided by these professionals. It is concluded that professionals seek to work in a humane way and treat patients with respect and ethics.
On the other hand, two elderly study participants mentioned that sometimes the professional does not promote proper communication before performing any procedure, as illustrated by the following speeches:

They have already arrived and only applied the medication, not explained. If the escort does not ask, they only apply and leave.

They arrive, simply make the procedures, they do not explain very well. Sometimes explain my companion.

Also in this sub-category, respondents talk about respect for their autonomy and practitioners must respect the will of the hospitalized elderly, without imposing any kind of conduct. Respect for the autonomy of the elderly is expressed in the following parts of the testimonies:

The professionals have to have respect for older people, not to insist on one thing that the elderly do not want to.

Here in the hospital I want to have a good assistance, attention, carefulness, that respects my desire. They are very helpful, give affection, always ask how everyone is, it is this.

\section{Category II. Rights respected by} professionals to provide assistance for the elderly

\section{Subcategory 1. Right to a humane and dignified assistance}

In this category, the interviews refer to the care provided by health professionals during the hospital stay. The care of the elderly is based on respect and humanized care evidenced in these statements: 
Law of the elderly is the doctor and nurses arrive and treat the elderly with care, as it should be. I think it is very important that respect and those rights. I believe that the elderly have their rights and they should be respected.

All they respect. Sometimes, when I am busy, they arrive, talk, I make up, and this is right, does not arrive with brutality. Treat everyone with love, all of them.

Respect, namely respect, and meet in a humane manner and dignified manner.

[...] they were very helpful in explaining the reasons and consequences of the disease that $i$ have, and have attitudes in relation to this situation. The care is humane, they explain.

Therefore, respect is essential in professional practice, as noted in the statement follow:

The professionals meet, they all relate, because if we do not respect [...] you can rest assured that I complain, because there is a right. If you do not give reason or space for them to disrespect, then you have the right to have a reaction.

\section{Subcategory 2. Respect to privacy, rest and sleep}

Respondents mentioned in their statements the rights respected by professionals, which included: privacy and respect to the time of sleep and the patient's home. Such understanding is exposed in the following testimony excerpts:

They always honor my sleep, never got someone to wake me up. Only when I am awake even, so they call me, they respect this time.
I am honored, treat as well, with respect, I have never had a problem with the professionals. Respect my sleep.

They respect my privacy, my sleep and rest, [...]; I have no complaint that $i$ was disrespected.

My privacy here inside is respected, very well respected.

On the other hand, some interviewees criticized the disrespect the time of sleep, and the noise made by professional teams, especially during the night shift, as shown by these statements:

[...] There was a professional, who woke me up, and I was in a sleep very good, talked to me and was though, then I felt a bit annoyed

Look, I already felt annoyed because I once had in which $i$ had to agree and the reason was not important. But apart from that, they respect. I did not meet my sleep that day.

Already there were times to agree without need. I felt upset, because you want to rest and you cannot rest, here comes someone, wakes up and disrupts at that time. But it is for this reason that I will fight, not only taste, because it is the time that I am resting.

[...] where he works a lot of people, things are never the same, has night that we're lying here, there is a noise, more $i$ leave it there, when I arrived here, they were already. Then the night makes a bit of noise [...]. But that noise sometimes bothers you, you know that sleep in the elderly is not as a young man, any little thing everybody agrees. 


\section{Discussion}

As it can be seen, this data differs from the standard admission of the Brazilian reality, where, in most situations, are the women who seek health services. However, in this study, male hospital was predominant. In this context, it is important to consider aspects of the health culture of the society, where men, early on, not in the habit of taking care of their health or seek assistance. This fact, over the years, leads to an increase in diseases in this population group, in which the diagnosis almost always will arise at later stages, and they will need more specialized care and a higher cost [16].

After analyzing the data, it was observed that $20 \%$ (4) of the participants are illiterate. In relation to this data, although education has advanced over the years, the reduction in illiteracy proportions occurs very slowly, and the elderly with a higher level of education are still scarce [17]. Low evidenced education in most interviewed elderly is an unfavorable social condition; it influences the opportunities for social participation, access of the elderly to health services understanding of their treatment and selfcare [18]. Therefore, little education, together with the socioeconomic and cultural factors, can contribute to the emergence of diseases due to factors such as the difficulty of making people aware of the need for health care for, maintain a healthy lifestyle and prevent risk factors, which will help to increase the number of hospitalizations of the elderly [19].

It was found in this study that most seniors reside with their spouse, so their nearest support. It should be emphasized that living with a family, but without the spouse's presence is a risk factor for the quality of life for seniors [20].

The average length of hospitalization of the elderly was of eight days. Regarding this data, it is significant that, due to illness, most often you need hospitalization, and patients are exposed to the risks of the hospital environment. However, these risks are compounded for some groups; one of them is the elderly who, due to the process of immunose- nescence to chronic diseases and the physiology of aging process, are more susceptible to infectious complications that ultimately extend the hospital time [21]. The number of times that the old was admitted to the institution where the research was being conducted, it was found that about 50\% (10) of the respondents were admitted for the first time.

Regarding the professional who most welcomes and assists the elderly during hospitalization, nurses stood out, with $80 \%$ (16). Considering this fact, the relationship between nurse and elderly patient in the hospital, takes its relevance at the time that the elderly are configured as the primary users of health care, and nurses, more present professionals in this context [11]. It is worth noting that health professionals, especially nurses who provide care to more closely patient must have the ability to understand themselves and each other and become aware of the values and principles that guide this action [22].

Considering the presented testimonials, highlights the concern of the elderly for the right to have a companion. In relation to this right, it is important that the stay of the companion in the hospital is already recognized by some users of the Brazilian health system, including the elderly, whose companions begin to act as facilitators in restoring health and as accelerators in the patient rehabilitation process admitted to hospitals [23].

The Elderly Statute provides in A 16 that, being hospitalized or under observation, the elderly have the right to escort, and the health agency must provide the right conditions for their stay. This statute provides that the health professional who is responsible for processing must grant permission for monitoring the elderly or, if not possible, to justify it in writing [24].

The Elderly Statute is embodied as a social conquest of great importance because it is a guarantee of the rights of this layer of society so vulnerable. But it is also necessary to raise awareness to occur in fact, the fulfillment of these rights. 
The Federal Constitution states that every Brazilian citizen is entitled to health. For the elderly, the prerogative is the same, which suggests a guided full assistance in the care of specific needs with this population [25]. Access to health care of the elderly covers a set of tactics and equipment that involve practices and care that promote independence and social inclusion of senile, in order to improve the quality of care [26].

The cited testimonies bring reflections about the practical application of health professionals and the disrespect of some professionals, because in their care practice, prioritized only the technical procedure and they forgot to inform the patient why and the importance of being carried out such a procedure.

Unfortunately, in some of the health care services, disease monopolizes the attention of some professionals, and in most cases, the priorities are the measures to contain the disease, and respect, individuality, dignity, patient rights, their preferences, values, beliefs, customs and feelings are secondary [27]. During the time of care, this type of professional conduct will reflect as impersonality, insensitivity and mechanization, although the technical and scientific knowledge are essential in this context.

It is important to reinforce that both patients have a right to know information about procedures and their health, as professionals have a duty to give them this information [28]. As can be seen when patients are respected and knowledgeable about their health, many of their needs are met, and caring so focuses on the individual, respect and autonomy. The communication, then, to be characterized as a soft technology, in order to meet the patient's needs, includes attentive listening and clear information [29].

The testimonies claim that the health care area should respect the will of the elderly and not insist on something they do not want. Respect for autonomy in assistance to the elderly should lead health professionals, in particular, Nursing, considering the capacity of choices, beliefs and moral values of the patient so that he carries on autonomy and decide between the care alternatives that are presented from the clear understanding of the consequences of each of them [5].

Based on the above, it requires care to respect the patient's right to make decisions about their condition and body. This is a way to exercise respect for human dignity and rights, as practice in the hospital routine. Through care, health professionals, especially those in nursing area, can contribute significantly to the construction of autonomy, with the participation of older persons in decision-making about their needs attention or care to their health [30].

From these reports, one can see that the survey participants value respect and humanized care, because they have adopted a friendly attitude and humanized care these seniors. Faced with this situation, the humanization of care is characterized as a set of initiatives that can combine the best available technology coupled with the promotion of acceptance and ethical-cultural respect to the patient [31]. Regarding the role of the nurse during assistance to hospitalized elderly patient, this professional relationship of care with the elderly is vital and should take place at all times: the acceptance of the health service, in performing procedures for the assistance and the guidelines for hospital discharge [32].

Nursing legislation establishes that nurses in the profession, should prioritize respect for life, dignity and human rights in all its dimensions [33].

This statement reinforces the importance of professional to respect the right of the elderly. In this approach, the health professionals should adopt an ethical position to show care and respect for the elderly, considering their ethical and legal rights, and understand the conditions that each individual experiences; thus, contributing to the respect of the rights they enjoy [34].

It is noticed that it is very important that the professional ensures comprehensive health care of the elderly, treating them with respect and dignity. This requires not only assistance guided the biological 
aspect of the disease, but also the ability to understand the patient as a whole human being, with their values, beliefs, desires, perspectives and, above all, rights to be respected.

From the testimonies, we can infer that the privacy and time of sleep and rest were respected. With regard to privacy, in fact, it is a necessity and human right for the preservation of his body, exposure and handling by another individual, and disrespect this right features its invasion. In this regard, the Code of Ethics of Nursing Professionals (CEPS), in Article 19, mentions that it is the duty and responsibility of nurses to respect modesty, privacy and intimacy of human beings [35].

As regards respect for the time of sleep, pointed out in the speech above, it should be noted that in a situation of disease, sleep is essential for the patient's recovery and help to prevent the onset of other diseases, because it is during sleep that the humoral and the immune system are recovered. For this reason, it is essential that sleep should be respected, and health professionals provide the necessary conditions for this moment to occur smoothly and as pleasant as possible [36].

As regards the lack of respect for the time of sleep, it is important to note that poor sleep is indicative of many diseases, and sleep disorders can negatively affect feelings, ideas and motivation of the individual [37]. One of the factors related to disregard about the time of sleep, it is cited by the respondent (I_03), as the noise provided by professional teams during the night shift, which impairs sleep of the elderly.

Therefore, health professionals need to be aware of customer expectations and understand the complexity and the magnitude of this vital step, respecting the rights of the hospitalized patient during the time of sleep and in their care practice.

\section{Conclusion}

With the results of this study, it was possible to understand the rights of hospitalized elderly according to their perspective. The right to have an escort was one of the most cited in the interviews; because, due to the great demand for care, the companion is essential in this process and acts as a facilitator in restoring the health of patients.

During the interviews, the right to health, to information and autonomy also emerged in the interviews. The reflections on the right to health presented by the participants were associated needs assistance for differentiated health, where the weaknesses that the elderly has to be recognized.

Regarding the right to information, it appears as necessary to strengthen the link between the professional and the patient, because when patients are informed about their treatment, their needs are met, and this reflects the quality of care, with humanized professionals and treat patients with respect and ethics. Regarding autonomy, it is considered the speeches as a right of choice of the elderly patient. It is for the health professional to consider the ability of the individual's choice.

Regarding the right to a humane and dignified care, participants appreciated humane care and respect dispensed by professionals during the time when the care is being performed. Thus, it is essential to guided assistance in respect that understanding the patient as a human being and not just focus on the biological aspect.

The elderly also mentioned the importance of privacy, rest and sleep. For some respondents, the timing of sleep and rest privacy was respected by professionals, especially nursing, because they have more contact with the elderly patient who needs a higher demand for care. They criticized the lack of explanation of procedures performed, disrespect to the time of sleep and the noise made by some professionals during the night shift. All this betrays a lack of respect and ethics of some professionals with the patient because experience the hospitalization process is not an easy time, since in most cases the elderly are fragile and need a quiet and comfortable environment, for the restoration of their health. 
The analyzed statements of this study showed the importance of the rights of hospitalized elderly patients and some of the rights they enjoy. Therefore, it is of every professional in the hospital environment to ensure that these rights are being respected and contribute to a humane and dignified care.

It is hoped, therefore, that further studies be carried out and to bring guiding subsidies in relation to the hospitalized elderly patient rights.

\section{References}

1. Banco Mundial. Envelhecendo em um Brasil mais velho: implicações do envelhecimento populacional para o crescimento econômico, a redução da pobreza, as finanças públicas e a prestação de serviços. Washington: Banco Mundial; 2011. Available from: http://siteres ources.worldbank.org/ BRAZILINPOREXT N/Resources/ 3817166-1302102548192/ Envelhecendo Brasil Sumario Executivo.pdf

2. Joia LC, Ruiz T. Satisfação com a Vida na Percepção dos Idosos. Satisfaction with Life Seniors' Perception. Rev Kairos. 2013; 16(6):79-102. Available from: http://revistas.pucsp.br/index. php/kairos/ article/ view/20023/14898

3. Prochet TC, Silva MJP. Percepção do idoso dos comportamentos afetivos expressos pela equipe de enfermagem. Perception of the elderly in the view of affective behaviors expressed by the nursing team. Esc Anna Nery Rev Enferm. 2011; 15(4):784-90. DOI: http://dx.doi.org/10.1590/S1414-81452011000400018

4. Piexak DR, Freitas PH, Backes DS, Moreschi C, Ferreira CLL, Sousa MHT. Percepção de profissionais de saúde em relação ao cuidado a pessoas idosas institucionalizadas. The perception of health professionals toward the care of institutionalized elderly. Rev Bras geriatr gerontol. 2012;15(2):201-8. DOI: http://dx.doi. org/10.1590/S1809-98232012000200003

5. Cunha XPC, Oliveira JB, Nery VAS, Sena ELS, Boery RNSO, Yarid SD. Autonomia do idoso e suas implicações éticas na assistência de enfermagem. Autonomy of the elderly and its ethical implications on nursing care. Saúde debate. 2012; 36(95):6574. DOI: http://dx.doi.org/10.1590/S0103-11042012000400018

6. Brasil. Lei $n^{\circ} 8.842$, de 4 de janeiro de 1994. Dispõe sobre a política nacional do idoso, cria o Conselho Nacional do Idoso e dá outras providências. Diário Oficial da União. 1994; 4 jan. [citado em 26 out 2014]. Available from: http://www.planalto. gov.br/ccivil 03/leis/l8842.htm

7. Brasil. Decreto $n^{\circ} 1.948$, de 3 de julho de 1996. Regulamenta a Lei $n^{\circ} 8.842$, de 4 de janeiro de 1994, que dispõe sobre a Política Nacional do Idoso. Diário Oficial da União. 1996; 3 jul. [citado 26 out 2014]. Available from: http://www.planalto.gov. br/ccivil 03/decreto/d1948.htm
8. Brasil. Portaria $n^{\circ} 2.528$ de 19 de outubro de 2006. Aprova a Política Nacional de Saúde da Pessoa Idosa. Diário Oficial da União. 2006; 19 out. Available from: http://www.jusbrasil.com. br/diarios/738747/pg-142-secao-1-diario-oficial-da-uniao-doude-20-10-2006

9. Santos G, Sousa L. Qualidade de vida em pessoas idosas hospitalizadas: comparação da admissão com a alta do internamento. Quality of life in hospitalized older persons: a comparison of admission to discharge from hospital. Rev Kairos. 2013; 16(2):07-25. Available from: http://revistas.pucsp.br/ index.php/kairos/article/viewFile/17625/13126

10. Lima OBA, Lopes MEL, Melo VC, Oliveira AMM, Acioly CMC, Alves AMPM. Hospitalized elderly rights: understanding of assistant nurses. J Nurs UFPE on line [Internet]. 2013 [Cited 2015 Oct 15]; 7(12):6954-62. Available from: http://www.revista. ufpe.br/revistaenfermagem/index.php/revista/article/view/5018 DOI: 10.5205/reuol.4767-42136-1-ED.0712esp201301

11. Lima OBA, Lopes MEL, Oliveira AMM, Carvalho GDA, Melo VC. Conduct of nurses in care of hospitalized elderly. J Nurs UFPE on line [Internet]. 2014 [Cited 2015 Oct 15]; 8(4):814-9. Available from: http://www.revista.ufpe.br/revistaenfermagem/ index.php/revista/article/view/5267. DOI: 10.5205/reuol.582950065-1-ED-1.0804201403

12. Gil AC. Métodos e técnicas de pesquisa social. 6 ed. São Paulo: Atlas; 2008. 200f.

13. Minayo MCS. Construção dos instrumentos e exploração de campo. In: Minayo MCS. O desafio do conhecimento: pesquisa qualitativa em saúde. 12 ed. São Paulo: Hucitec; 2010. $407 f$.

14. Bardin L. Análise de Conteúdo. Lisboa: Edições 70; 2011. $280 f$.

15. Brasil. Ministério da saúde (MS). Conselho Nacional de Saúde. Comissão de Ética e Pesquisa. Resolução n 466/2012 sobre pesquisa envolvendo seres humanos. Brasília: DF; 2012. Available from: http://conselho.saude.gov.br/resolucoes/2012/Reso466.pdf

16. Silveira RE, Santos AS, Sousa MC, Monteiro TSA. Gastos relacionados a hospitalizações de idosos no Brasil: perspectivas de uma década. Expenses related to hospital admissions for the elderly in Brazil: perspectives of a decade. Einstein (São Paulo) [Internet]. 2013 [cited 2015 Aug14];11(4):514-20. DOI: http://dx.doi.org/10.1590/S1679-45082013000400019

17. Faller JW, Melo WA, Versa GLGS, Marcon SS. Qualidade de vida de idosos cadastrados na Estratégia Saúde da Família de Foz do Iguaçu-PR. Quality of life for elderly registered in the family health strategy (fhs) of Foz do Iguaçu-PR. Esc Anna Nery Rev Enferm. 2010; 14(4)803-10. DOI: http://dx.doi.org/10.1590/ S1414-81452010000400021

18. Santos GS, Cunha ICK. O. Avaliação da qualidade de vida de mulheres idosas na comunidade. Evaluation of quality of life of elderly women in community. Rev enferm Cent-Oeste Min. 2014; 4(2):1135-45. DOI: http://dx.doi.org/10.19175/recom. v0i0.593 
19. Pereira RA, Santos EB, Fhon JRS, Marques S, Rodrigues RAP. Sobrecarga dos cuidadores de idosos com acidente vascular cerebral. Burden on caregivers of elderly victims of cerebrovascular accident. Rev ESC Enferm. USP [Internet]. 2013 [cited 2015 Aug 15];47(1):185-192. DOI: http://dx.doi. org/10.1590/S0080-62342013000100023

20. Moliterno ACM, Faller JW, Borghi AC, Marcon SS, Carreira L. Viver em família e qualidade de vida de idosos da universidade aberta da terceira idade. Living with the family and the elderly's quality of life at the senior citizens' open university. Rev enferm UERJ. 2012;20(2):179-84. Available from: http:// www.e-publicacoes.uerj.br/index.php/enfermagemuerj/article/ view/4040/2802

21. Izaias EM, Dellaroza MSG, Rossaneis MA, Belei RA. Custo e caracterização de infecção hospitalar em idosos. Cost and characterization of hospital infection among the elderly. Ciênc saúde coletiva [Internet]. 2014 [citado 02 jun 2015]; 19(8):3395-02. DOI: http://dx.doi.org/10.1590/141381232014198.12732013

22. Trentini M, Paim L, Vásquez ML. A responsabilidade social da enfermagem frente à política da humanização em saúde. Social responsibility of nursing in policies of health humanization. Colomb med. 2011; 42:95-102. Available from: http://www. scielo.org.co/scielo.php?script=sci arttext\&pid=S165795342011000500012\&lng=en\&nrm=iso\&tlng=pt

23. Sanches ICP, Couto IRR, Abrahão AL, Andrade $M$. Acompanhamento hospitalar: direito ou concessão ao usuário hospitalizado? Hospital treatment: right or concession to the hospitalized user?. Ciênc. saúde coletiva [Internet]. 2013 [citado 25 Jun 2015]; 18(1):67-76. DOI: http://dx.doi.org/10.1590/ $\underline{\mathrm{S} 1413-81232013000100008}$

24. Brasil. Ministério da Saúde (MS). Estatuto do Idoso. Brasília: DF; 2003. Available from: http://conselho.saude.gov.br/biblioteca/ livros/estatuto idoso2edicao.pdf

25. Silva JRG, Galdino MNAS, Bezerra ALD, Sousa MNA. Direito à saúde: revisão Integrativa da literatura sobre o acesso de idosos aos serviços de Saúde. C\&D-Revista Eletrônica da FAINOR. 2012; 5(1):25-42. Available from: https://www. researchgate. net/publication/286084284 DIREITO A SAUDE REVISAO INTEGRATIVA DA LITERATURA SOBRE O ACESSO DE IDOSOS AOS SERVICOS DE SAUDE

26. Girondi JBR, Santos SMA. Deficiência física em Idosos e Acessibilidade na Atenção Básica em Saúde: Revisão integrativa da literatura. Physical disability in the elderly and accessibility on primary health care: integrative review of the literature. Rev gaúch enferm [Internet]. 2011 [citado 27 jun 2015]; 32(2):37884. DOI: http://dx.doi.org/10.1590/S1983-14472011000200023

27. Pupulim JSL, Sawada NO. Percepção de pacientes sobre a privacidade no hospital. Patients' perception about privacy in the hospital. Rev bras enferm [Internet]. 2012 [citado 10 jun 2015]; 65(4):621-29. DOI: http://dx.doi.org/10.1590/S003471672012000400011

28. Policastro D. Erro médico e suas consequências jurídicas. 3 ed. Belo Horizonte: Del Rey; 2010. p.330.
29. Fontana RT. Humanização no processo de trabalho em enfermagem: uma reflexão. Humanization in the process of working in nursing: a reflection. Rev Rene. 2010; 11(1):200-7. Available from: http://www.revistarene.ufc.br/vol11n1 html site/a21v11n1.htm

30. Carretta MB, Bettinelli LA, Erdmann AL. Reflexões sobre o cuidado de enfermagem e a autonomia do ser humano na condição de idoso hospitalizado. Reflections on the care of nursing and the autonomy of the human being under the condition of hospitalized elderly. Rev bras enferm. 2011; 64(5):958-62. DOI: http://dx.doi.org/10.1590/S0034-71672011000500024

31. Mendes J, Spíndola TS, Mota GMC. Percepção de pacientes sobre a equipe de enfermagem acerca da humanização em terapia intensiva. Perception of patients about the nursing staff on humanization in intensive care. Rev Enferm UFPI. 2012;1(3):182-7. Available from: http://www.ojs.ufpi.br/index. php/reufpi/article/view/825/pdf

32. Eliopoulos C. Enfermagem Gerontológica. 7 ed. Porto Alegre: Artmed; 2011. 568f.

33. Conselho Federal de Enfermagem (COFEN). Resolução COFEN $N^{\circ}$ 311/2007 aprova a reformulação do código de ética dos profissionais de enfermagem. Rio de Janeiro; 2007.

34. Moraes JCO, Brito FM, Costa EO, Barros EO, Costa IP. O Idoso e seus Direitos em Saúde: Uma Compreensão Sobre o Tema na Realidade Atual. The elderly and their health rights: a perspective of the current reality Rev bras ciênc saúde. 2014; 18(3): 255-60. DOI:10.4034/RBCS.2014.18.03.10

35. Pupulim JSL, Sawada N. O. Privacidade física referente à exposição e manipulação corporal: percepção de pacientes hospitalizados. Physical privacy regarding body exposure and manipulation: perception of hospitalized patients. Texto \& contexto enferm. 2010; 19(1):36-44. DOI: http://dx.doi. org/10.1590/S0104-07072010000100004

36. Alves Júnior DR. Repercussão do sono sobre o trabalho. Diagn tratamento. 2010; 15(3):150-2. Available from: http://files.bvs. br/upload/S/1413-9979/2010/v15n3/a1566.pdf

37. Costa SV, Ceolim MF. Fatores que interferem na Qualidade do Sono de Pacientes internados. Rev esc enferm USP [Internet]. 2013 [citado 12 jun 2015];47(1):46-52. DOI: http://dx.doi. org/10.1590/S0080-62342013000100006

\section{Publish in International Archives of Medicine}

International Archives of Medicine is an open access journal publishing articles encompassing all aspects of medical science and clinical practice. IAM is considered a megajournal with independent sections on all areas of medicine. IAM is a really international journal with authors and board members from all around the world. The journal is widely indexed and classified Q2 in category Medicine. 